\title{
What to do when the results are insufficient: lessons from the excavation of a cairn field at Eikebakken, Øvre Øksnevad, Klepp
}

\author{
THEO GIL BELL AND SEAN D. DENHAM
}

Bell, T. G. \& Denham, S. D. 2020. What to do when the results are insufficient: lessons from the excavation of a cairn field at Eikebakken, Øvre Øksnevad, Klepp. AmS-Varia 61, 61-75, Stavanger, ISSN 0332-6306, ISBN 978-82-7760-187-8

The cairn field at Eikebakken, Øvre Øksnevad, Klepp municipality, Rogaland, Norway, was excavated over the course of 26 weeks in the summer of 2016. The site had undergone an initial survey in 2008, indicating a total of 79 cairns. However, when the site was uncovered a total of 103 stone built structures were identified, as well as three separate settlement areas and evidence of prehistoric farming. The initial project plan and budget were written with the idea of focusing on a smaller number of more thoroughly excavated (i.e. single-context) cairns. The increased number of structures made this plan untenable. As the excavation progressed it also became clear that the single-context method was not returning the amount of data required. The excavation thus went through several major shifts in strategy in response to, primarily, the archaeology and the need to develop a representative data set, but also time/budgetary constraints and available labor resources. The strategy ultimately settled upon involved a much more rapid excavation of a larger number of cairns with a focus on the use of environmental evidence from the cairns, particularly material suitable for radiocarbon dating, but also a range of other methodologies, as a means of understanding the development of the cairn field. This article will discuss both the methodologies and prioritizations involved in the excavation and will present some brief, initial results.

Theo Gil Bell, Museum of Archaeology, University of Stavanger, N-4036 STAVANGER, NORWAY.

E-mail: theo.gil@uis.no

Sean D. Denham, Museum of Archaeology, University of Stavanger, N-4036 STAVANGER, NORWAY.

E-mail: sean.d.denham@uis.no

Keywords: burial cairns, gravefields, sampling strategies, Øvre Øksnevad

\section{Introduction}

Cairn fields are inherently complex sites. At the best of times, excavating this type of site raises a number of theoretical and logistical challenges. When time and budgetary restrictions are a major factor, the ability to prioritize certain aspects of the site, perhaps at the expense of other archaeological features, is essential. This requires specific definitions of what one wishes to identify and record, what one considers an acceptable level of documentation and what one considers a representative sample. At the same time, one must be prepared to adapt excavation strategies if and when the initial prioritizations are not producing the desired amount of data. The 2016 excavations of a large cairn field at Eikebakken, Øvre Øksnevad, Klepp municipality, in southwestern Norway provide an instructive example of these problems.
The following article will focus on two general themes, methodology and initial results. The excavation of the Eikebakken, Øvre Øksnevad site was challenging, and the excavation and sampling strategies evolved over the course of the project. It is worthwhile, therefore, describing how the excavation was conducted, as well as when, how and why methodologies were adapted. Some discussion of the utility/efficiency of various strategies may also prove useful in planning future excavations. Although post-excavation work is ongoing at the time of writing, some basic descriptions of the results will hopefully illustrate the complexity of the site.

\section{Eikebakken, a gravefield overlooking Frøylandsvatnet}

The cairn field of Eikebakken at Øvre Øksnevad, Klepp, was spread across the top and southeastern slope 
Fig. I. Map depicting location of $\varnothing$ vre $\varnothing$ ksnevad, Klepp municipality, Rogaland as well as the placement of the Eikebakken site in the landscape. Map: T. G. Bell, AM, UiS.

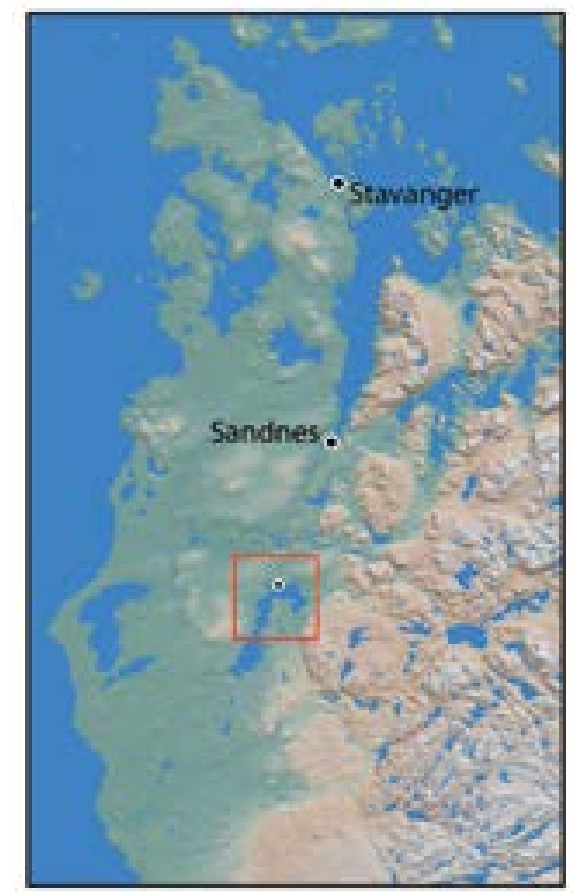

of a glacial moraine on the northwest edge of Lake Frøylandsvatn (Fig. 1). The moraine deposits consist primarily of finer sand (indeed, it is the extraction of this finer sand for industrial usage which is one of the reasons the site is being developed), although the upper layers are a mixture of coarser sands, gravel and stones. The topsoil coverage across the site was relatively thin, particularly over the cairns themselves, indicating slower soil development combined with erosive processes. The surrounding landscape is similarly hilly and dotted with lakes and low-lying wetlands of various sizes.

The archaeology of the area shows evidence of constant activity from the Late Neolithic through the Iron Age. An excavated burial cairn at nearby Nedre Øksnevad produced Migration Period (AD 400-550) finds, with Neolithic stone implements and possible settlement found beneath (Braathen, 1978). Two burial cairns, a clearance cairn and settlement evidence were excavated at a separate site at Øvre Øksnevad, $800 \mathrm{~m}$ to the north of Eikebakken, in 1996. The two burial cairns were dated to the Bronze Age (1700-500 BC) and the Pre-Roman Iron Age (500 BC-0) (Skauen, 1997). The nearby site at Håbakken produced settlement evidence from the Neolithic Period as well as the Late Bronze Age (1000-500 BC) and Pre-Roman Iron Age (Hemdorff, 1987). As will be seen, this agrees well with what is seen in the cairn field at Eikebakken.

As far back as Helliesen (1906), it was noted that in addition to the two monumental cairns on the top of the moraine, several smaller cairns were located further down the slope, although an exact count was not

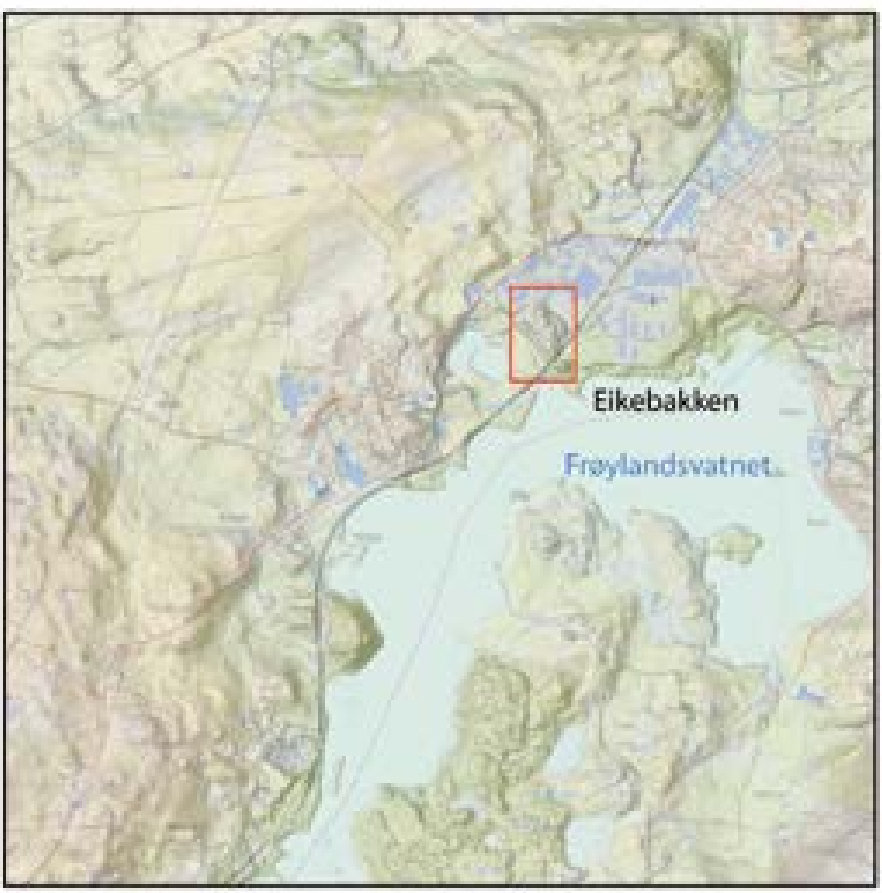

available. It is assumed that almost half of the cairns, located in the western side of the slope have been lost since this initial survey. A 1983 survey identified 63 cairns in the area.

In 2008, the site was resurveyed in advance of the excavations described in the current article and a number of test trenches dug. This work suggested a total of 79 cairns visible on the surface of the site. Threedimensional modelling of the site in advance of the excavation confirmed this. In addition, the trenches revealed isolated cooking pits and farming layers on the lower section of the field (Fyllingen, 2008).

\section{Excavation strategy in the project plan}

Based upon the previous survey work, the initial excavation strategy divided the staff into two teams of five. The first team was to focus specifically on the two larger cairns (Cairns 1 and 2) for the entire length of the excavation, eleven weeks on Cairn 1 and fifteen on Cairn 2. The second team would spend the first eleven weeks stripping the topsoil from the field, and the final fifteen weeks excavating a representative number of the smaller cairns on the middle and lower terraces. This would allow for $20 \%$ of the 79 cairns identified during the registration phase to be fully excavated using single-context methods. Settlement evidence was to be down-prioritized. This last was purely a practical matter. It was decided that the time and budgetary constraints were such that one could not satisfactorily excavate both the cairn field and any settlement evidence. Given the extent of the cairn field, 


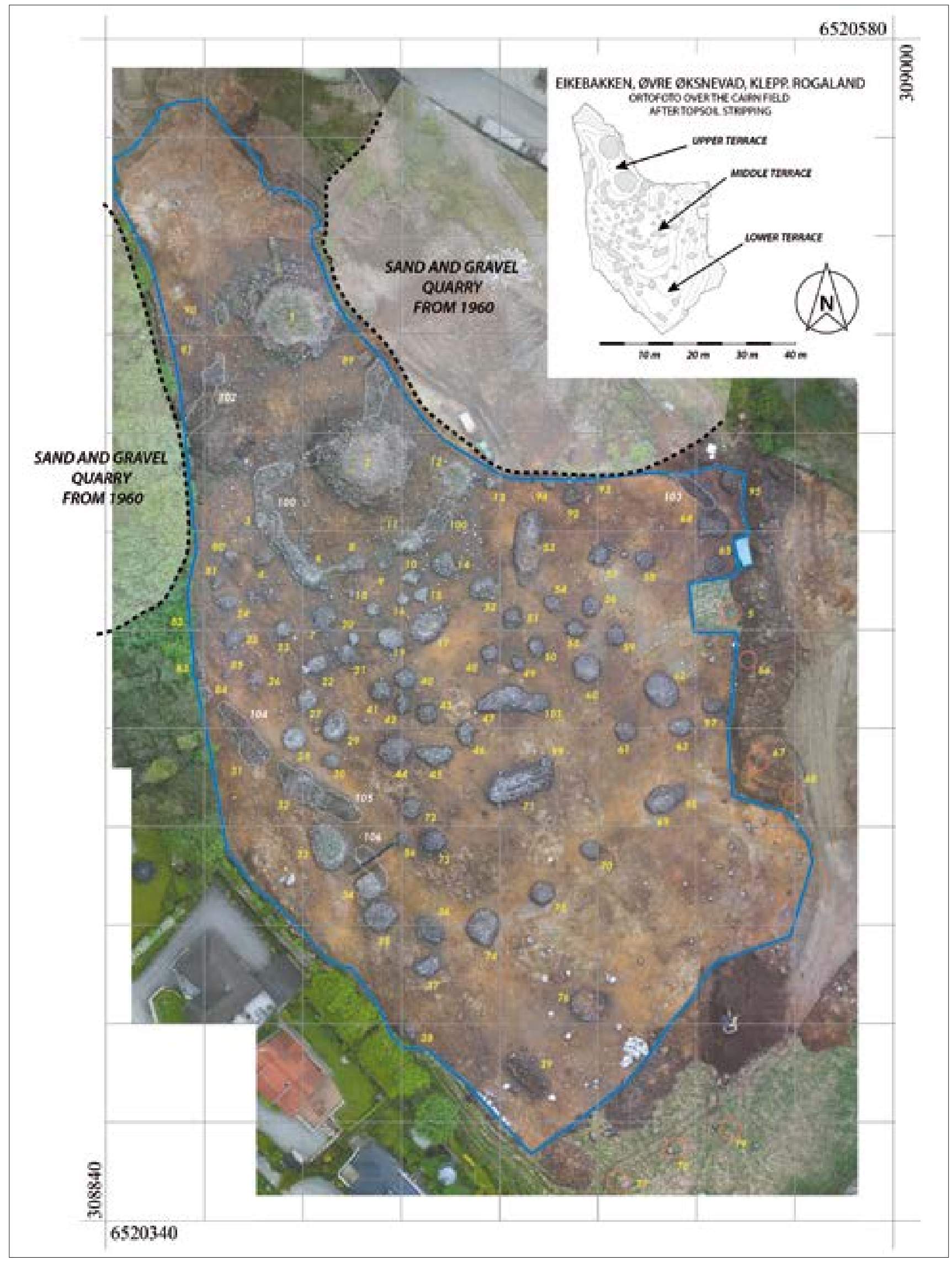

Fig. 2. The cairn field at Eikebakken, Øvre Øksnevad, Rogaland, after surface soil stripping. Individual structures are numbered. Extended bands of stones are highlighted in white. Cairns not uncovered at the time of photography are circled in red. Illustration: T. G. Bell, AM, UiS. 
Fig. 3. Cairn groupings based on perimeter length $(\mathrm{m})$ and surface area $\left(\mathrm{m}^{2}\right)$. Illustration: T. G. Bell, AM, UiS.

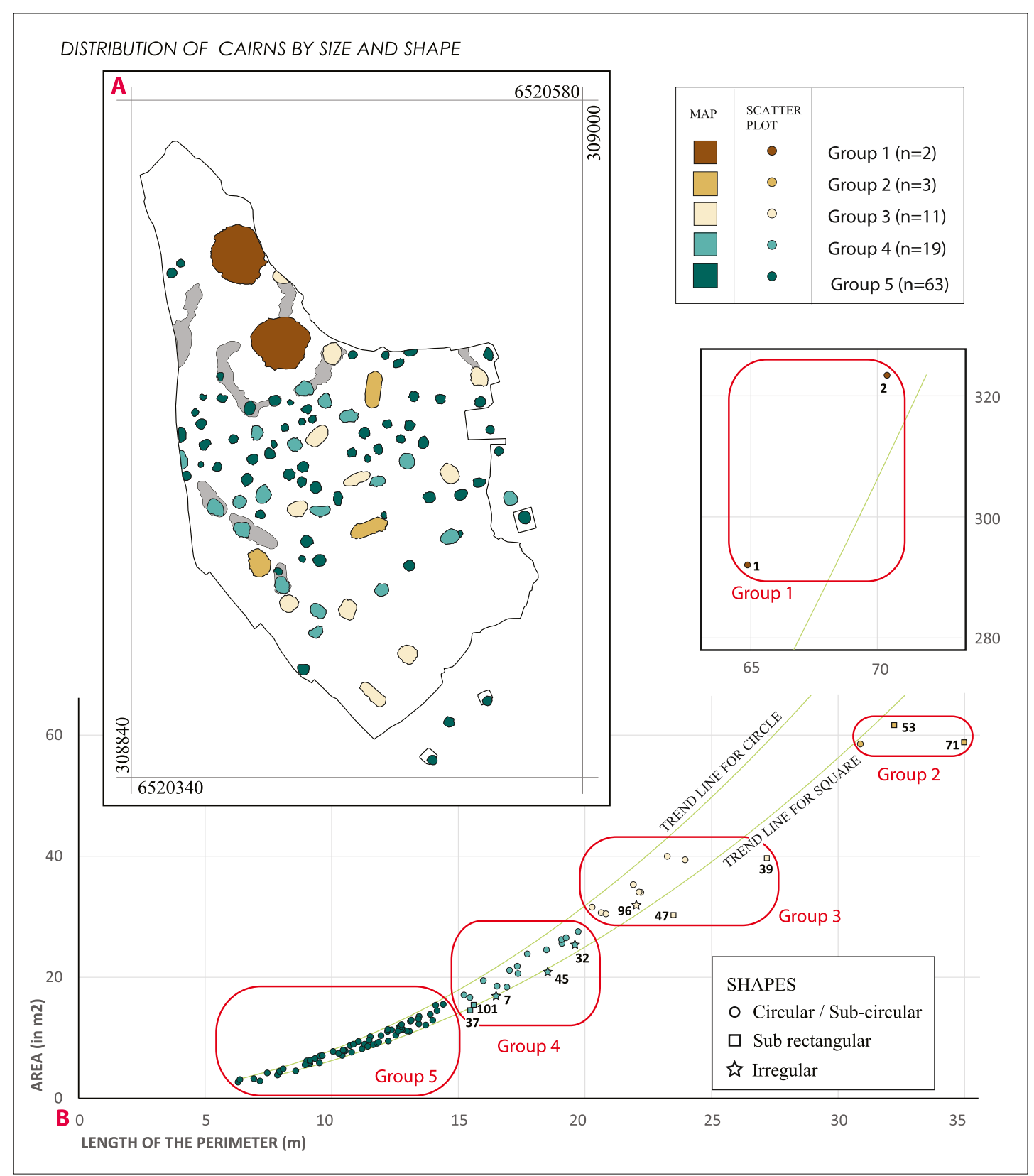

the infrequency with which these sites are excavated, and, conversely, the frequency with which prehistoric settlement evidence is excavated in Rogaland, the cairn field was determined to be of greater importance.

\section{A gravefield with settlement evidence}

The site was excavated over a period of six months in 2016. The stripping of the topsoil across the site progressed extremely efficiently, due to both the effectiveness of the mechanized digger operator and the rather shallow topsoil coverage. Several previously undetected cairns and a considerable amount of settlement evidence were uncovered during the process.

Upon surface stripping the entire site, the number of cairns increased greatly, with a total of 103 stone built structures being uncovered (Fig. 2). Although many of these were circular/sub-circular in shape, elongated cairns and other stone assemblages were also identified. One of these, a linear stone structure (Structure 100) partially encircles Cairn 2 and appears to serve a boundary between that cairn and the rest of the field. In addition, three settlement areas and intermittent farming layers were identified. It was unclear during excavation whether these farming layers all represent the same phase of activity.

\section{Cairns}

For descriptive purposes, the cairn field can be divided into three areas: the upper, middle and lower terraces, each bearing cairns/stone built structures of various 
sizes. In terms of size, it is possible to distinguish five general groups of cairns based on plotting the perimeter length against the surface area (Fig. 3). Group 1 represents the two most prominent features (Cairns 1 and 2). Each one of these is circular in shape and ca. $20 \mathrm{~m}$ in diameter, with a surface area of over $300 \mathrm{~m}^{2}$. These two cairns are adjacent to each other on the upper terrace.

Groups 2 and 3 are evenly distributed across the two lower terraces. The cairns within each of these groups are well dispersed, separated by an average distance of $15 \mathrm{~m}$. The two groups show a larger variation in shape than Groups 1, 4 or 5, and include the largest number of sub-rectangular cairns on the site. It is worth mentioning that two cairns in Group 3 (cairns 39 and 76) are located on the southern side of the field and are far removed from the main distribution of cairns.

Amongst the last two groups, we can observe an even distribution of cairns, primarily on the two lower

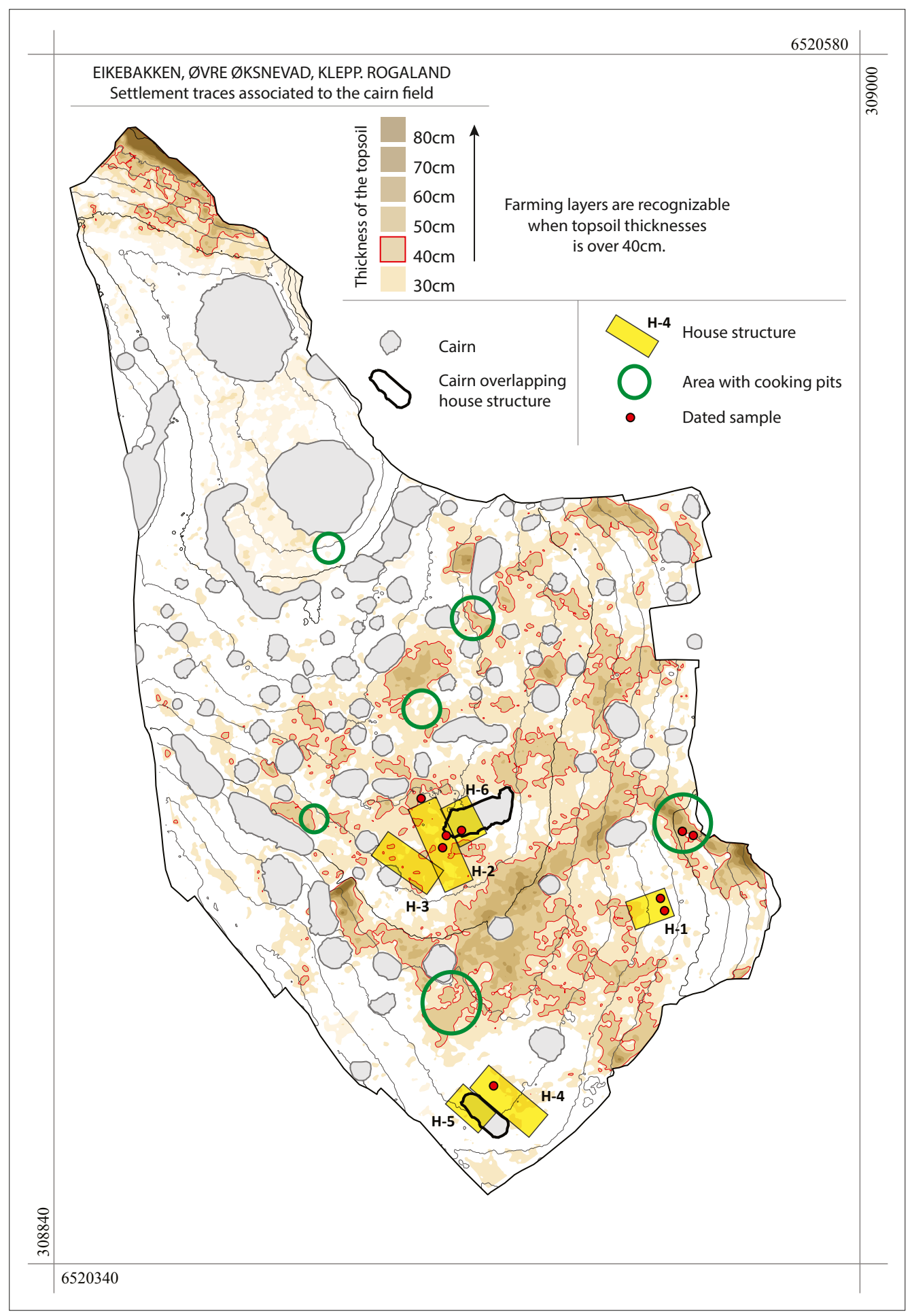

Fig. 4. Settlement evidence on the Eikebakken site. Illustration: T. G. Bell, AM, UiS. 

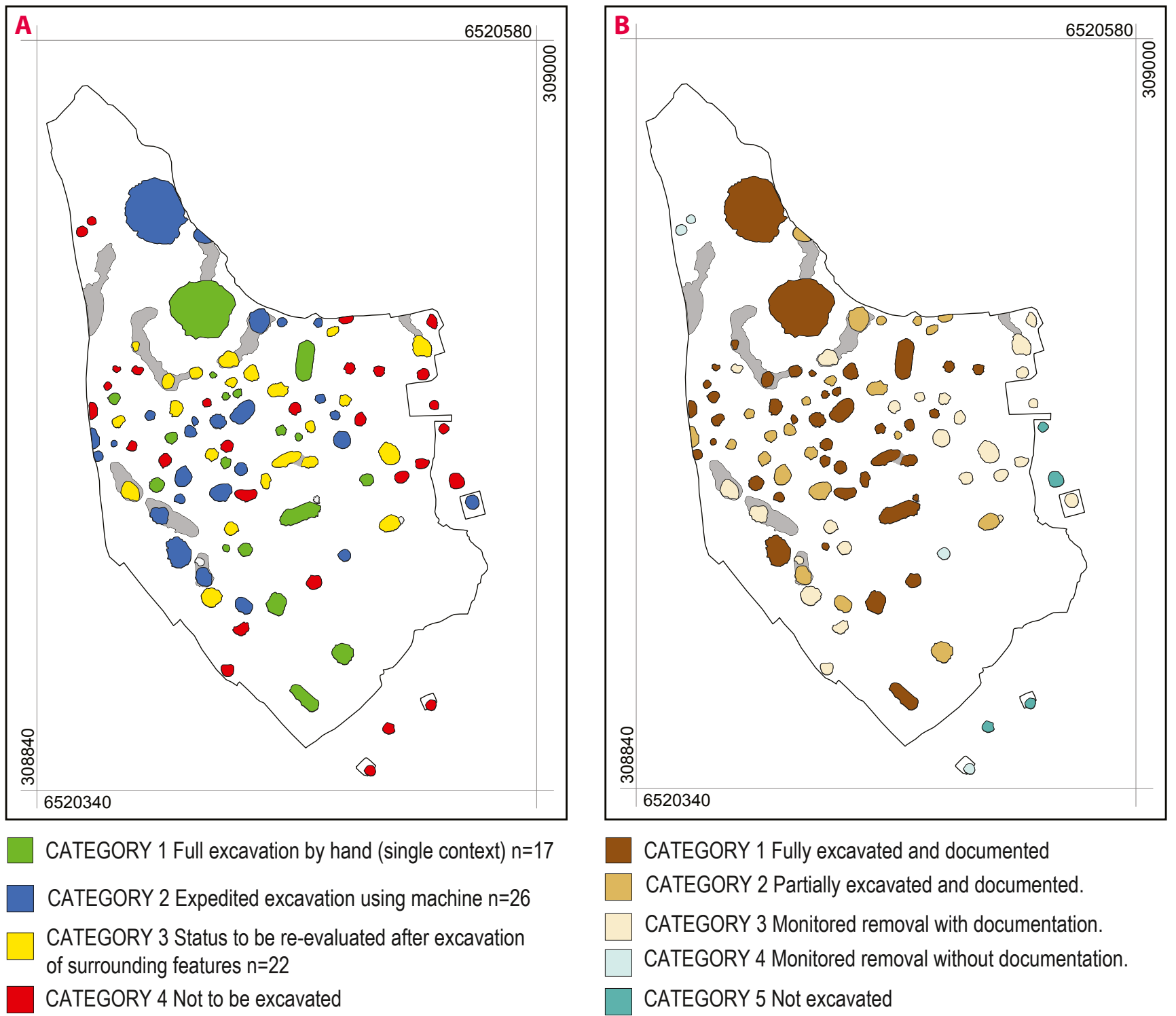

Fig. 5a. Cairn excavation strategy adopted after initial stripping of topsoil. Illustration: T. G. Bell, AM, UiS.

Fig. 5b. Cairn excavation strategy adopted mid-way through the excavation. Illustration: T. G. Bell, AM, UiS.

terraces. Group 4 contains the second largest number of cairns, occasionally forming clusters of 3 to 4 cairns of similar size. The shapes of these Group 4 cairns appear slightly more irregular than those in Group 5, most being defined as sub-circular. Group 5, the largest of the five groups $(n=60)$, is comprised of the smallest cairns on the site. The size of these varies between 2 and $4 \mathrm{~m}$ in diameter and the overwhelming majority are circular in shape. A large number of structures within this group are located on the upper section of the middle terrace. Cairns within this group are generally placed in close proximity to each other. Several Group 5 cairns are also located along the outskirts of the cairn field.

\section{Settlement traces}

Close to 400 postholes, fireplaces and cooking pits were located in three distinct areas, two on either side of the lower terrace and one in the center of the middle terrace. In total, six houses have been defined, three of which were located on the middle terrace (Fig. 4). The houses are relatively short in length, composed by two parallel rows of paired postholes and, in some instances, a fire pit along the long axis of the house. Few of the wall postholes have survived. While the remains of four of the houses are very distinct, Houses 4 and 6, without clearly associated fireplaces, are more difficult to substantiate. In addition, these last two houses were found overlapped by cairns. The overall distribution of the houses does not seem to indicate contemporaneity, but rather the juxtaposition of buildings with similar characteristics over an uncertain period of time. Un-phased posts have been 
documented in close connection to two of these settlement areas and should be seen in relation to these. In addition, isolated cooking pits have been documented north of the settlement area on the middle terrace and west of House 1, partially overlapping fossilized farming deposits.

\section{Fossilized farming deposits}

Remains of fossilized farming deposits have been identified in close connection with these settlement areas. These deposits have accumulated on the steep slopes below the middle terrace with an additional pocket of preservation below cairn 53. Five profiles transecting these deposits have been documented and sampled. Below the middle terrace a series of cairns have been documented overlapping the farming sequences.

\section{What to do? Initial prioritization and development of an excavation strategy}

The large number of cairns and other archaeological remains define Eikebakken as a complex site. Its excavation, in relation to the allocated budget, required both a strong prioritization and flexibility.

It was first necessary to adapt the initial excavation strategy, in terms of both the number of cairns to be excavated and the level to which they would be excavated, keeping in mind the need to develop a representative dataset. A number of issues drove this slight adjustment to the initial excavation strategy. First, the initial plan of fully excavating 15 smaller cairns as well as the two monumental cairns was always seen as insufficient, but was dictated by budget limitations. This was an attempt to address that problem. Second, and more significantly, was the $36 \%$ increase in number of stone constructions identified on the site after the stripping of the topsoil. In addition, scheduling and establishing time limits for each cairn would allow a better managing of the excavation.

After a majority of the field had been uncovered, the exposed cairns were assigned to one of four different categories (Fig. 5a). This took into consideration the location, size, external appearance, proximity to similar structures and available resources.

14 cairns were assigned to Category 1,18 to Category 2. The 22 cairns in Category 3 were to be re-evaluated as the excavation progressed and according to the results from the explored cairns. Each cairn in the two first groups was assigned a specific time limit according to its size and the selected method of excavation. Although the method by which these were estimated was admittedly not rigorous, it helped to outline an excavation schedule and maximize the use of the mechanical excavator.

According to this plan, all cairns within category 1 and 2 would require 45 working weeks (37.5 hours per working week) to excavate and document, with a 30 working week buffer built in for the Category 3 cairns as well as any unforeseen circumstances. Results from the Category 1 cairns would form the main data set, with those cairns from Category 2 confirming or invalidating the trends seen in that set. The Group 1 cairns were to be excavated via the single-context method. Single-context, also known as stratigraphic excavation, involves the excavation/documentation of individual stratigraphic contexts with a feature. This has been shown to be an effective strategy when excavating in-ground burials (Evis et al., 2016), and had the added benefit of working well with our primary form of documentation (photo mosaics/photogrammetric modeling). Over the succeeding weeks, however, it became clear that this was not optimal. The primary problem was the lack of finds in the cairns; more specifically, the lack of discrete, dateable burial contexts, but also finds and structural elements which might be used to link various cairns. Figure 6 illustrates the progression of the single-context excavation of Cairn 42. As can be seen, there was no internal structure or organization. In this situation, transitions between stratigraphic contexts can be challenging to recognize, and there is a great amount of subjectivity involved. Thus, it is extremely difficult to identify what can or should be sampled for dating and/or environmental evidence. Cairn 42 was typical of attempts to excavate cairns via single-context methods.

\section{Adaptability}

The inability to rely upon fewer, more carefully excavated cairns to provide a representative data set forced another change in strategy, and the idea of complete, single-context excavation of select cairns on the middle and lower terraces was abandoned. Midway through the excavation, therefore, the strategy was replaced with a much more rapid excavation process where half of the cairn was excavated either by hand or with active use of the digging machine, with a focus on identifying structural elements and find concentrations. The exposed profile would be documented and sampled for environmental evidence, and then depending on the results, the remaining part of the cairn would be excavated either by hand or with the help of a mechanical excavator. The excavation of the second half of the cairn was intended to verify the 
Fig. 6. Progression of single context excavation of Cairn 42, highlighting the limited potential of this method to identify absence of discrete burial contexts or distinct layers. Photos: Flo Reidarsdatter. dateable contexts in the
Fig. 7. Profile through Cairn 75, illustrating the sampling surface available using the expedited excavation method adopt mid-way through the T. G. Bell, AM, UiS. excavation. Illustration:
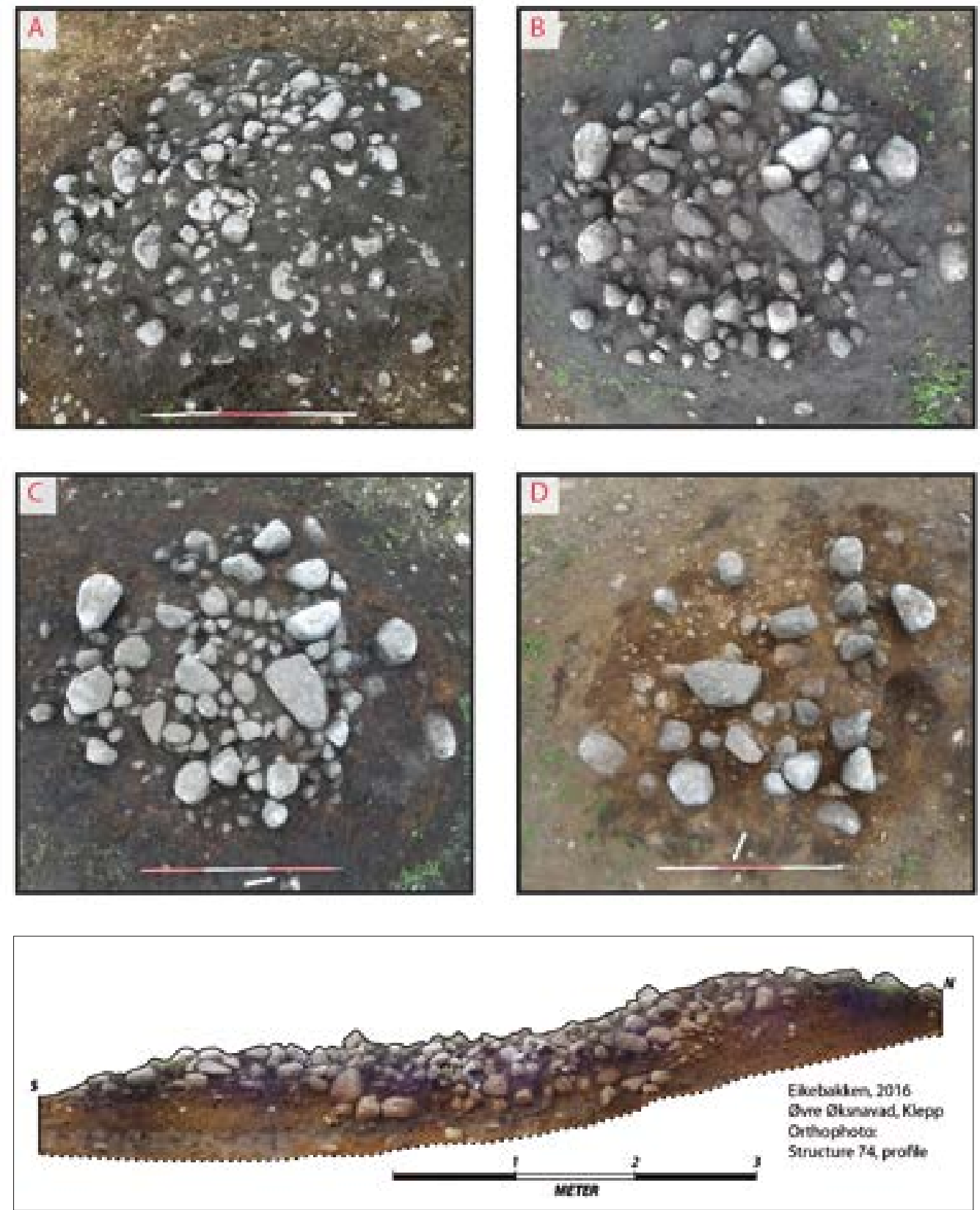

presence/absence of structural elements and to make sure no definable features were missed. In some few instances, profile benches were cut through the middle of the cairns, but this strategy was quickly abandoned. Figure 7 illustrates the type of profile one is presented with when excavating in this manner. As part of this process of adaptation, emergency funds were allocated by the Directorate for Cultural Heritage, allowing us to increase the excavation staff and thus proceed with the excavation of the largest cairn. This result-oriented approach had a positive impact in terms of find frequency and overall sampling strategy.

By focusing more heavily on the environmental evidence from both the cairns themselves and the surrounding soil layers as a means of identifying various phases in the development of the cairn field, it became apparent that the settlement traces needed to be excavated. It must be emphasized that this shift from the detailed excavation of fewer cairns to a more general excavation (for lack of a better term) of a larger number of cairns was only undertaken after it was established that the former strategy was not producing the necessary data. In an ideal situation, a comprehensive data set, with each cairn quantified via a standard set of variables, would be developed. In practice, this was not realistic since the cairns had varying levels of evidence associated with them. While the focus shifted towards identifying appropriate deposits for environmental sampling, the finds and clearly definable structural elements were excavated responsibly. 
Table I. Overview of the level to which the cairns in the various groups were excavated.

\begin{tabular}{|l|c|c|c|c|c|c|}
\hline Level of & Fully excavated & $\begin{array}{l}\text { Partially } \\
\text { excavated }\end{array}$ & $\begin{array}{l}\text { Monitored removal } \\
\text { with documentation }\end{array}$ & $\begin{array}{l}\text { Monitored } \\
\text { removal without } \\
\text { documentation }\end{array}$ & Not excavated & Total \\
\hline Group 1 & 2 & & & & 2 \\
\hline Group 2 & 3 & 4 & 3 & & 3 \\
\hline Group 3 & 4 & 6 & 5 & 4 & 11 \\
\hline Group 4 & 7 & 13 & 17 & & 19 \\
\hline Group 5 & 25 & & & & 3 \\
\hline
\end{tabular}

The shift in strategy, as well as the increased staffing levels, described above, allowed for a much larger number of cairns to be explored (Fig. 5b, Table 1). In total, 65 cairns out of 98 where explored and sampled to acceptable standards, 42 of these were fully excavated. This includes all the cairns in Groups 1 and 2, and over $30 \%$ of the cairns in the remaining groups. A further 25 cairns were subjected to expedited investigation, although no immediate results could be obtained. Finally, settlement evidence from the three separate areas (originally down-prioritized) as well as some more enigmatic linear stone structures were able to be investigated.

\section{Efficiency}

An attempt was made to keep accurate track of the hours used on each cairn. This was generally successful, although there were some inconsistencies in the tracking process. Only 32 of the excavated cairns for which we have information have been deemed to have reliable hour usage data associated with them. There are, of course, many factors which go into the length of time it takes to excavate a cairn, the size of the cairn, excavation strategy, the number and skill level of the excavators, weather, fatigue level. Figure 8 plots the size of the individual cairns (surface area) against the amount of time taken to excavate them (for those instances for which we have reliable data). Surface area is used here not because it is the best measure of a cairn's size, but because it is easier to estimate a cairn's surface area during a surface registration than its volume. Thus, from a planning perspective, this is the information which will be available when budgeting for excavation. A linear regression line through the data has a reasonable coefficient of determination associated with it, suggesting, unsurprisingly, a general correlation between cairn size and length of excavation time. If one focuses in on the cairns between 10 and $25 \mathrm{~m}^{2}$ in size, one can see much greater variability (i.e. more values either well above or well below the trend line). Although one must be careful when interpreting this data, some general trends can be seen. Of the five cairns that fall well above the trend line (i.e. which took longer to excavate than the general trend would suggest necessary), three of these were excavated according to the single-context method, while another required more extended excavation due to a large pottery concentration. All of the seven cairns which fall significantly below the trend line were excavated either by staff members hired mid-way through the excavation, who were thus less fatigued, using more efficient excavation strategies, or a combination of both. In terms of hours per $\mathrm{m}^{2}$, these two groups represent the opposite ends of the spectrum, the former requiring the longest amount of time per $\mathrm{m}^{2}$ ( $\max =7.5 \mathrm{hrs}$.), the latter the shortest $(\mathrm{min}=1.2 \mathrm{hrs}$.). This huge variation illustrates how decisions made both during the planning phase and in the field have a great effect on efficiency, and should be taken as instructive for future excavations.

One further point should be made regarding excavation efficiency and it has to do with the documentation techniques. It was decided early on to assign

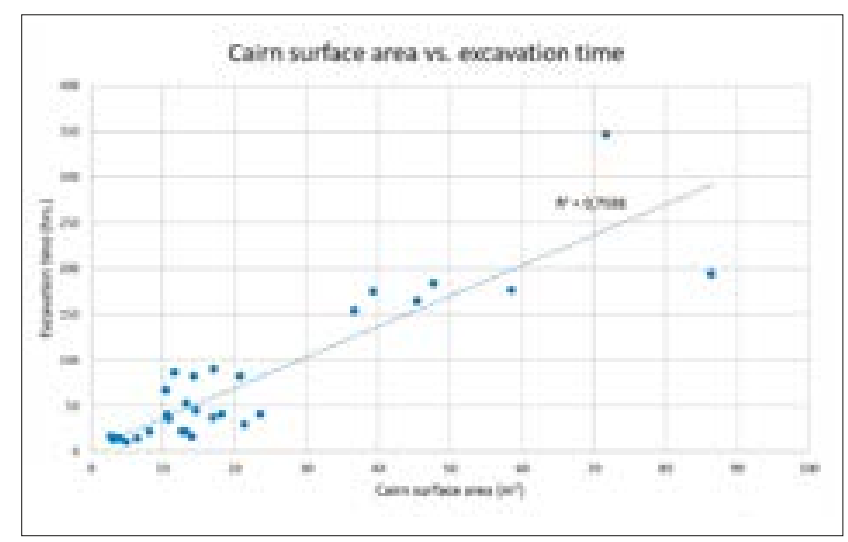

Fig. 8. Excavation efficiency, cairn surface area $\left(\mathrm{m}^{2}\right)$ vs. total excavation hours required per cairn. Cairns I and 2 are not included. Illustration: S. Denham, AM, UiS. 
one staff member to oversee the documentation/data being produced. The documentation process adopted for this excavation was extremely computer intensive, and involved producing multiple photomosaics each day, as well as three-dimensional, photogrammetric models. It was also necessary to assess the quality of the digital photos to ensure they were appropriate for photogrammetry. This needed to be done in real time in order to avoid delays in excavation. Furthermore, each documented layer of each structure was provided with a unique recording sheet, bearing digitized photos of the layer to aid in note taking. The only way to achieve this efficiently was to have one staff member coordinate the entire process. This eventually grew to two staff members, and without these data specialist positions, the excavation would not have proceeded as efficiently as it did.

\section{General environmental sampling}

Environmental sampling of archaeological features is a standard practice. In the present case, as mentioned above, the lack of finds/discrete, dateable burial contexts in the cairns led to an increased focus on the environmental evidence as a means of tying together the various areas of the field. This included sampling of profiles through the various farming layers identified on the middle and lower terraces as well as the cairns themselves, the surfaces below the cairns and settlement features. Reference samples were also taken from the natural subsoil in various areas of the field as well as from features identified as clearance cairns. Table 2 details the sampling strategy.

The interplay of these various sampling contexts, particularly those involving cairns, is complex. A basic schematic of the situation can be seen in Figure 9. Several types of context can be seen:

- RF - Cairn fill, upper layer

- RF2 - Cairn fill, lower layer

- F1 - Contexts possibly related to burial activity (ceramic concentrations, distinct charcoal layers, pits centrally located beneath the cairn)

- D1 - Farming layer sealed by cairn structures

- D2 - Farming layer not sealed by cairn structures

- B - Paleo surface sealed by cairn

- E1 - Slash-and-burn layer sealed by cairn

- E2 - Slash-and-burn layer not sealed by cairn

- F3 - Features not related to, but sealed by cairn

- F2 - Features not related to, and not sealed by cairn

- U - Mineralogical underground

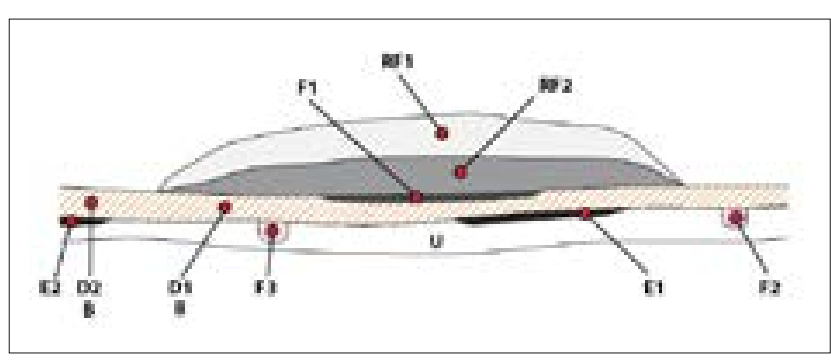

Fig. 9. General schematic of possible layers encountered when excavating cairns. Illustration: T. G. Bell, AM, UiS.

These all may seem fairly straightforward, and that all samples have been obtained from clearly distinguishable features/contexts. However, there are many smallscale post-depositional processes which might affect the security of a given context. At a broader level, not all of these contexts are present in every situation. This is particularly problematic with the variable appearance of the farming layer and the variable relationship of the cairns to the farming layer. We have to take into consideration the morphological characteristics of these cairns as well as their placement in the landscape when evaluating what samples to take.

\section{Sampling cairns for radiocarbon dating}

Interpreting the post-depositional processes involved in the formation of the cairn field in Eikebakken is closely related to obtaining a series of reliable radiocarbon dates from the excavated structures. As it has been previously pointed out, establishing a prior sample-context relationship for much of this dataset was problematic due to the insufficiency of secure archaeological contexts from which these samples were retrieved. In addition, the inherent difficulties of carrying out an excavation project of this scale, within a limited timeframe, had an unavoidable impact in the sampling strategy.

In the absence of a discrete burial context with bone which can be dated, or diagnostic finds, finding dateable material one can reasonably associate with the burial event is a challenge. Charcoal or charred cereal grains can easily be redeposited, or washed in, particularly in shallower cairns of the type seen at Eikebakken. Compounding the problem is the extremely slow process of soil development on this site, which left the surfaces of these cairns more or less exposed since their construction. Even in situations where a charcoal sample appears to have undergone relatively little postdepositional disturbance, it is difficult to say with any certainty that that charcoal actually dates the burial/ construction of the cairn. This is due to the fact these many of these cairns overlay earlier activity areas. So not only is there the potential of contamination by later 
material working its way in from above, but by earlier material from below, having been redeposited during cairn construction (Boaretto, 2009). Few of the cairns produced bone in the quantities and contexts necessary for radiocarbon dating.

Charcoal samples were taken from the various layers of the cairn fill, wherever possible from beneath stones which appeared to have undergone little post-depositional movement. Cairns generally had up to three fill layers. In order to limit human error, one experienced staff member was assigned the task of sampling every cairn for dateable material. This involved not only identifying where best to sample from, but fine-sieving the sample in the field in order to ensure sufficient charcoal was recovered. In situations where a sample produced insufficient amounts of charcoal, the staff member was able to go back and sample more from that context, something which would have been impossible if the samples had been processed in the post-excavation phase.

\section{Selecting which cairns to date}

The project budget allowed for a maximum of 50 radiocarbon dates, and it was decided to send separate batches, using the results of the first to aid in the selection of samples for the second. No samples were sent while the excavation process was ongoing. At the time writing 38 samples from cairns, farmings profiles, cooking pits and postholes have been dated. When selecting which cairns to date via charcoal, two aspects needed to be considered:

1. Does the cairn have viable samples (i.e. sufficient amounts of the appropriate species) from both its upper and lower fill layers?

2. Where in the field is the cairn located?

Finding viable samples became a problem. In spite of best efforts to ensure sufficient amounts of charcoal when sampling in the field, this could only be taken so far. Without a wood identification specialist on site, one cannot do more than recover as much charcoal as possible from appropriate contexts and hope it will be viable for radiocarbon dating. In the present case, the first batch of samples sent for wood identification contained very few viable samples. This required a change in strategy, both in terms of amount and species. In some cases, the minimum threshold of $0.01 \mathrm{~g}$ per sample was ignored, in others, less ideal species such as ericaceae sp. (heather) were used.

Preferably, only cairns with viable samples from both their upper and lower fill layers would be selected, the dating of both the upper and lower layers hopefully narrowing down the date range of the cairn. It must be stated that the lack of topsoil coverage/sealing layers over the cairns meant that dating samples for the upper layers of the cairn fill had great potential for later contamination. Furthermore, a representative distribution of cairns from across the field was desirable. With the exception of two instances where bone was sent (cairns 1 and 33), all contexts were dated using palaeobotanical material. Figures 10a and 10b illustrate the location and types of samples sent for dating.

Table 3 displays the dating results. Given the archaeology of the surrounding area, the available dates and finds from the 2008 registration, and the finds on the site, dates ranging from the later Neolithic through the Early Iron Age were expected, with the cairns primarily dating to the Early Iron Age. It is immediately apparent that several samples are significantly younger than expected (medieval or later). Two important points need to be made regarding these. First, all but one of these younger samples come from the upper levels of the cairns, suggesting heavy and constant mixing of modern material. This was not unexpected, given that few if any of these cairns had a sealing deposit, but it was perhaps necessary to demonstrate. Second, all but one of the younger dates come from heather (ericaceae), a family of shrubs which tolerate a wide range of environmental conditions. It is further worth noting that no samples of heather produced dates within the expected range, or earlier.

An in depth discussion of these dating results goes beyond the scope of the present article, which seeks to focus primarily on practical issues connected to the excavation process and some brief description of the results. It is enough to highlight that once one eliminates all aberrantly late dates, the rest of the results fall more or less in line with the expectations outlined in the previous paragraph, activity on the site from the Late Neolithic through the Iron Age, with a majority of the activity associated with the cairns dating to the Late Bronze Age/Pre-Roman Iron Age. The early dates, recovered from various cairn fills, highlight the problems of attempting to date burial cairns from charcoal fragments recovered from the fill as opposed to material from discrete burial contexts.

\section{Cairn structure}

Although a wide variety in the dimensions and layout of the cairns was observed, it is possible to abstract certain generalizations. In terms of size there is a large 
Table 2. Environmental sampling strategy: context types sampled per methodology.

\begin{tabular}{|c|c|c|c|c|c|}
\hline & Plant Macrofossils & Pollen & Soil micromorphology & Soil chemistry & Radiocarbon dating \\
\hline Farming profile & $\bullet$ & $\bullet$ & $\bullet$ & $\bullet$ & $\bullet$ \\
\hline Cairn profile & - & - & $\bullet$ & $\bullet$ & • \\
\hline Cairn, underlying surface & & $\bullet$ & & $\bullet$ & $\bullet$ \\
\hline $\begin{array}{l}\text { Clearance cairn, profile } \\
\text { (reference sample) }\end{array}$ & • & - & $\bullet$ & $\bullet$ & $\bullet$ \\
\hline $\begin{array}{l}\text { Clearance cairn, underlying } \\
\text { surface (reference sample) }\end{array}$ & & & & • & \\
\hline $\begin{array}{l}\text { Natural subsoil, not overlying } \\
\text { structures (reference sample) }\end{array}$ & & & & • & \\
\hline Settlement evidence & ? & & & & - \\
\hline
\end{tabular}

\section{SAMPLES RELATED TO THE CAIRN FILL LAYER (RF1-RF2)}

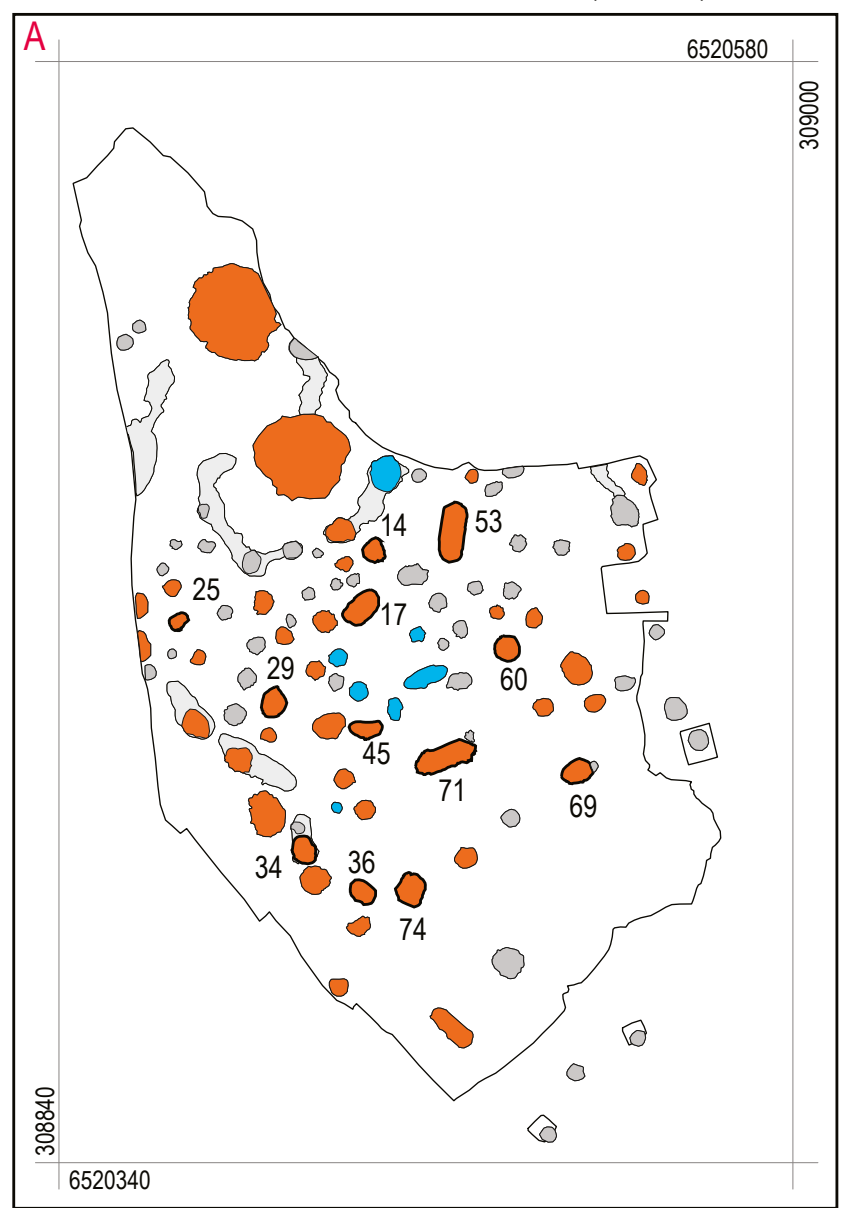

Not sampled cairn

Bottom part of cairn layer sampled

Top and bottom part of cairn layer sampled

Dated sample (with cairn nr.)

\section{SAMPLES RELATED TO POSSIBLE BURIAL CONTEXTS (F1)}

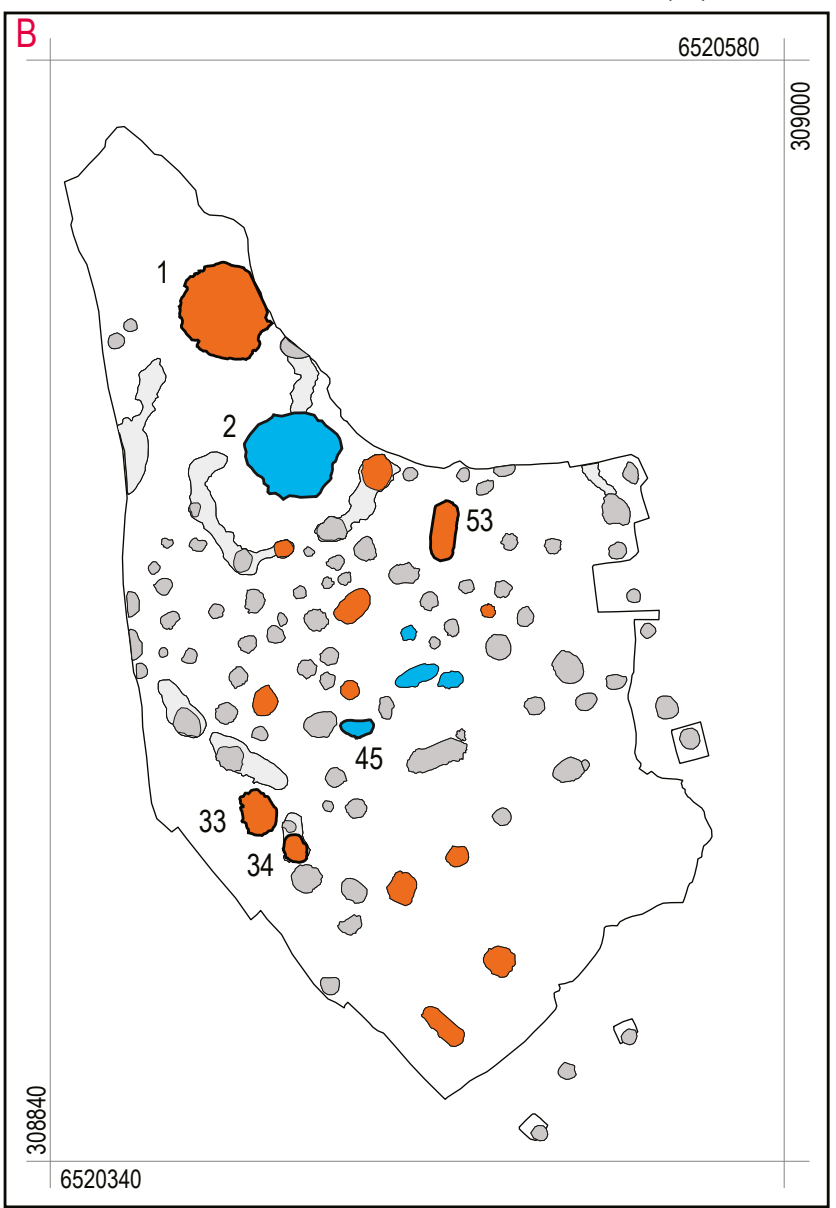

Cot sampled cairn

Unsecure context

Secure context

Dated sample (with cairn nr.)

Fig. 10a. Sampled cairn fill layers (RFI-RF2), dated samples have cairn number listed. Illustration: T. G. Bell.

Fig. IOb. Sampled secondary contexts (FI) possibly associated with burial activity, dated samples have cairn number listed Illustration: T. G. Bell, AM, UiS. 
Table 3. Radiocarbon dating results from the initial batch of datings of both cairn contexts and settlement/farming related contexts.

*These two dates come from human bone, all other dates from charred material.

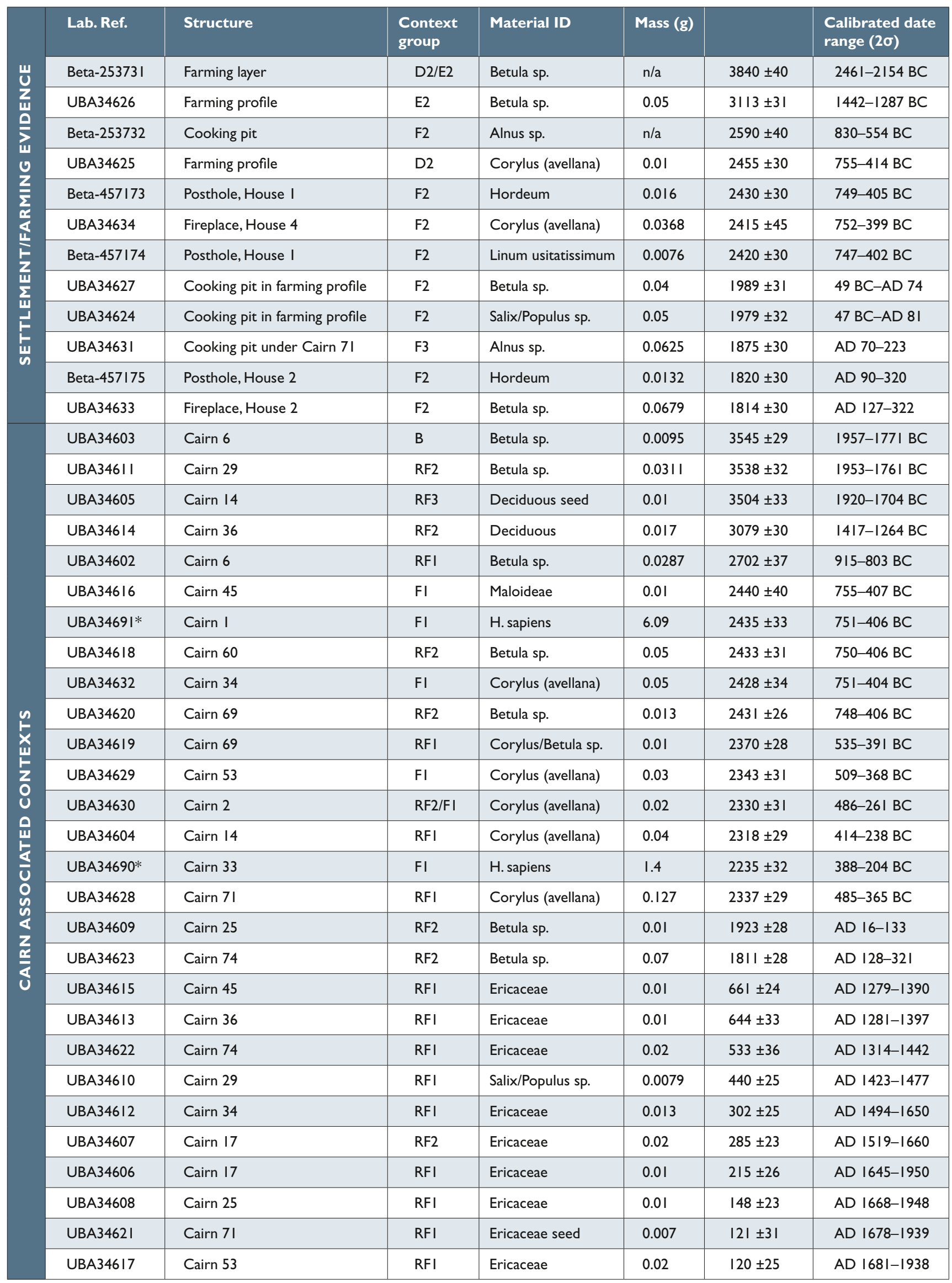


variation, although most of the field is composed by cairns smaller than $4 \mathrm{~m}$ in diameter. Shapes also vary, from elongated, almost rectangular to completely circular, with an overwhelming tendency towards subcircular shapes.

Regarding the presence/absence of structural elements among the cairns, the subjective nature of their identification needs to be stressed. Although in some cases the structural elements are clear, in many cases the perceived structural elements are much subtler, as in the case of circular or elongated arrangements of stones either in the subsurface or within the main cairn build up.

The ability to identify these types of structures, should they be present, is heavily dependent upon the skill of the excavating archaeologist. Conversely, factors such as confirmation bias and pareidolia (the tendency of the brain to perceive patterns where none exists) can lead to such features "being created" by the archaeologist during the excavation process. Some of these arrangements appear to have been intended as burial chambers, but as the size of the stones used to construct these structures shrinks, and becomes identical to those used in the surrounding cairn structure, it becomes difficult to judge whether or not these are real phenomena or wishful excavation. When evaluating the validity of these features, it is best to involve several individuals, particularly individuals not excavating the particular feature in question.

Nevertheless, there are some features which are unambiguous. The presence of elements such as perimetral kerbs, concentric circles of stone within the cairn itself, lined stones and deliberate sorting of the construction material attests to most of these cairns having been intentionally constructed rather than randomly accumulated as the result of agricultural clearance. The variability in the use of structural elements not only over time but in contemporaneous burial traditions (Bennett, 1987; Gansum, 2004) makes it difficult to interpret what one is seeing when such features are present. This raises an interesting problem. Many of these structural elements, for instance stone sorting or discrete burial chambers (for clearly there are instances of burial cairns without discrete chambers), would not have been visible in the generations after their construction. Without prior knowledge it would be impossible for one to know whether or not any of these were present. But, if they were not meant for communication with the living (i.e. the living could have no knowledge of their existence), what was their purpose? The addition of later structural elements, in the form of secondary burial chambers, speak to the relevance of these monument types across generations (Dahl, 2016). This type of re-use, however, is more of a redefining of the cairn's relevance to contemporary society than merely a memorial. Is it perhaps that some of these other elements, again stone sorting is a useful example, are also a part of this process of redefinition? Rather than stone sorting being seen as the product of a single construction event, perhaps the various layers represent distinct, unrelated construction events, used to re-establish the relevance of the cairn to contemporary society in the same way that secondary burial did.

The two larger cairns on the site (Cairns 1 and 2) show another interesting structural feature. These cairns take advantage of topography to provide monumentality and maximum visibility and, rather than being constructed entirely of stones, as with the other cairns on the site, actually consist of a relatively thin shell of stones, dressing peak in the underground which had been shaped for the purpose. This feature is critical to our understanding of this site overall. The shallowness of the stone dressing, particularly around Cairn 2, does not allow space/depth for a proper burial chamber. This leads to questions of the nature of the assemblages found among these structures.

\section{Finds}

Although a large number of the cairns provided no trace of the activity that originated them, a percentage of these did produce finds. The presence of cremated human bone, layers of fragmented ceramic vessels, and in a few instances personal items such as two soapstone pearls or flint artifacts makes these assemblages consistent with ritual activity associated to cremation burial practices and has been documented in similar sites (Dommasnes, 1997; Wangen, 2009). In addition, other more conspicuous finds such as iron slag, fragments of shells, sharpening stones, flint flakes and fragmented millstones in connection to these assemblages could be seen in relation to this type of activity.

\section{Burnt bone}

In the present context, finds of bone would have been ideal. As bone is directly connected to the funerary process, dating bone fragments from cairns would be the best possible way of dating the cairns themselves. Unfortunately, very little archaeological bone was recovered from this site, and in all cases burnt. Only two cairns, 1 and 33, produced significant amounts of bone. The dating results for these were reported above, 
and place these cairns in the Pre-Roman Iron Age. It is the depositional context of these bone finds that is interesting. In neither case was the bone found in a discrete deposit. In Cairn 33, the bone was found mixed in amongst the stones of the cairn fill, while in Cairn 1 the bone appears to have been deposited prior to the build-up of the cairn. The lack of a distinct charcoal layer associated with this level may indicate that the body was first cremated elsewhere, and then a representative amount of bone recovered from the pyre and spread out across the ground surface upon which the cairn was built. This process perhaps also explains the lack of a discrete burial context, or chamber in Cairn 1.

\section{Pottery}

Although pottery fragments are a common find in many of the cairns, most of them are non-diagnostic and therefore cannot assist in a more precise chronology other than Early Iron Age.

Pottery is generally found fragmented and mixed throughout the cairns. There are only a few instances where pottery appears in discrete concentrations suggestive of an in situ burial urn. Fragmentation of pottery has earlier been associated with burial practices in Bronze and Early Iron Age, and deserves more attention, but this too is beyond the scope of this article. Other finds may be seen in relation to this practice, for instance fragmented quern stones recovered from a number of cairns.

\section{Concluding remarks}

Work on this material, particularly the palaeobotanical and soil micromorphological samples, is ongoing. At the time of writing, the project has a budget for twelve more radiocarbon dates. No further samples from cairn fill layers will be dated. Instead, much of the focus will be on developing more robust chronologies for the environmental evidence. A particular emphasis will be placed on understanding the development of the various agricultural layers across the site. The ultimate goal of this aspect of the project will be a better understanding of the site's environmental history. How does the construction of the cairn field relate to the periodic phases of occupation seen at the site? Are these distinct events or is there overlap between phase of occupation and periods of cairn construction? What type of funerary traditions can be seen in the cairns? Are they consistent or do they vary?

This article has attempted to communicate the complexity of this monument and site type and provide examples of our attempts to deal with that complexity. It has also been shown how decisions made early in the planning process can have serious consequences for excavation efficiency, and how radical shifts in strategy are sometimes necessary. It seems that wider ranging, more general data sets have a greater potential for identifying burial traditions than incredibly detailed excavations of smaller numbers of cairns. Future excavations of cairn fields will therefore need to be very specific in what they're looking for and how they choose to look for it, if they wish to achieve this goal efficiently. Some of the lessons taken from the methodological aspects of the Eikebakken project will hopefully provide some guidance in this respect.

\section{References}

Bennett, A. (1987). Graven - religiös och social symbol. Theses and papers in North-European archaeology 18. Institute of Archaeology, Stockholm University.

Braathen, H. (1978). Øksnevadfunnet - en foreløpig melding. Frá haug ok heiðni 3, 79-81.

Boaretto, E. (2009). Dating materials in Good Archaeological Contexts: The Next Challenge for Radiocarbon Analysis. Radiocarbon 51:1, 275-281.

Dahl, B. (2016). Haugen som gravfelt. In W. Brun \& E. S. Pedersen (Red.), Tverrfaglige perspektiver 3, 77-96. AmS-Varia 58. Museum of Archaeology, University of Stavanger,.

Dommasnes, L. H. (1997). Tradisjon og handling i førkristen vestnorsk gravskikk. I. Undersøkelser på et gravfelt på Vereide i Gloppen, Sogn og Fjordane. Arkeologiske rapporter 21, Arkeologisk Institutt, Museumsseksjonen Bergen Museum, Universitetet i Bergen, Bergen.

Evis, L. H., Hanson, I. \& Cheetham, P. N. (2016). An experimental study of two grave excavation methods: arbitrary level excavation and stratigraphic excavation. STAR: Science \& Technology of Archaeological Research, 2:2, 177-191.

Fyllingen, H. (2008). Arkeologiske registreringer og forundersøkelser på Øvre Øksnevad, gnr. 8, bnr. 8, Klepp k., Rogaland. Oppdragsrapport B 2008/25. Arkeologisk Museum, Universitetet i Stavanger.

Gansum, T. (2004). Hauger som konstruksjoner - arkeologiske forventninger gjennom 200 år. Gotarc Series B. Gothernburg Archaeological Theses No. 33.

Helliesen, T. (1906). Oldtidslevninger i Stavanger amt. Klep sogn og pgd, Stavanger Museums Aarshefte 1905, 36-96.

Hemdorff, O. (1987). Langhus fra slutten av bronsealder - funnet på Håbakken i Klepp. Frá haug ok heiðni 3, $228-235$.

Skauen, I. (1997). Utgraving av gravrøyser og bosetningsspor på Øksnevad, Klepp kommune. Frá haug ok heiðni 1, 39-42.

Wangen, V. (2009). Gravfeltet på Gunnarstorp i Sarpsborg, Østfold: et monument over dødsriter og kultutøvelse $i$ yngre bronsealder og eldste jernalder. Norske Oldfunn XXVII/2009. Kulturhistorisk museum, Universitetet i Oslo. 